\title{
Feto-maternal outcome in subject undergoing epidural labour analgesia with Ripovacaine and Fentanyl
}

\author{
Madhu K. N., Dileep Kumar H. R.*
}

Department of Obstetrics and Gynecology, JJM Medical College Davangere, Karnataka, India

Received: 12 December 2017

Accepted: 08 January 2018

\section{*Correspondence:}

Dr. Dileep Kumar H. R.,

E-mail: diliphr.24@gmail.com

Copyright: (C) the author(s), publisher and licensee Medip Academy. This is an open-access article distributed under the terms of the Creative Commons Attribution Non-Commercial License, which permits unrestricted non-commercial use, distribution, and reproduction in any medium, provided the original work is properly cited.

\begin{abstract}
Background: Epidural anaesthesia is regional anaesthesia that blocks pain in particular region of the body. The present study was done to observe the effect of epidural analgesia and active management of labour on duration of labour and mode of delivery.

Methods: Main source of data were Primigravida inpatients from hospitals attached to JJM Medical College, Davangere from October 2016 to September 2017. It was a clinical cross-sectional study.

Results: It was observed that duration of labour was comparatively less in epidural group than control group. There was no significant increase in duration of II stage of labour in epidural group. There was no increase in both the instrumental delivery rate and caesarean section rate and also noted higher newborn APGAR score rate in parturient who received epidural analgesia.

Conclusions: The present study showed that there is no increase in the duration of labour or any increase in the rate of instrumental delivery or caesarean section in parturient receiving epidural analgesia, instead, there is a downward trend in all the above outcomes.
\end{abstract}

Keywords: Duration of labor, Epidural analgesia, Mode of delivery

\section{INTRODUCTION}

The distress and pain, which women often endure while they are struggling through labour, are beyond description and seem to be more than human nature would be able to bear, under any other circumstance Sir James Young Simpson 1848.

Labour is defined as series of events that takes place in genital organs in an effort to expel the viable products of conception out of womb through the vagina into the outer world.

Labor pain is one of the most, severe distressing situations experienced by woman in labour. The epidural labour analgesia still remains the "gold standard" of obstetric pain management, up till now. So far there has been no single ideal drug to overcome the superiority of the epidural analgesia in obstetrics.

Labour pain in the first stage is transmitted via $\mathrm{A}$ and $\mathrm{C}$ fibers along with sympathetic fibers into the spinal cord at T11-T12. There is a variable contribution from T10L1. As labour progresses, afferent fibers from cervix, vagina, and perineum pass via the pudendal nerve to S2S4. ${ }^{2}$

The pain pathways can be modified by both nonpharmacological and pharmacological methods of analgesia. Provide superior pain relief in the first and second stage of the labour. Facilitate parturient cooperation during the labour and delivery. ${ }^{3,4}$ Provide 
analgesia for episiotomy and the instrumental assisted delivery. Allows the extension of anesthesia for caesarean delivery if needed. Avoids opioid induced maternal and neonatal respiratory depression due to intravenous opioid administration.

The epidural analgesia is an extremely effective and popular treatment for labour pain. The use of epidural analgesia in the developed countries has tripled between 1981 and 2001, with $60 \%$ of parturient using the technique in major hospitals. ${ }^{5}$

Effective pain relief reduces plasma noradrenaline, prevents the rise during the first and second stage of labour of 11-hydroxy corticosteroid and prevents the metabolic acidosis by reducing the rate of rise of lactate and pyruvate. It decreases maternal oxygen consumption by up-to $14 \%$.

Also, it has been observed that provision of the labour analgesia has the potential to decrease the incidence foetal acidosis and improve cardiovascular and pulmonary function in the mother. ${ }^{6}$

The epidural analgesia not only the beneficial effect in the form of pain relief. It also has effects on the characteristics of labour and hence in the present study the feto maternal outcome in epidural labour analgesia and duration of labour and mode of delivery is evaluated. ${ }^{6}$

\section{METHODS}

The main sources of data for the study are women with full term in a labour attending hospitals attached to JJM Medical College, Davangere.

It was a clinical cross-sectional study carried out at JJM Medical College, Davangere from October 2016 to September 2017. Total sample size was 120 . The study particpants were grouped into two groups:

- Group A study group $\mathrm{n}=60$

- Group B controls $n=60$

\section{Inclusion criteria}

- Primigravida with the term a singleton pregnancy with vertex presentation with spontaneous labor with intact membranes

- Patient must be in established labor and fulfill following criteria,

- Cervical dilatation minimum of $4 \mathrm{cms}$.

- Cervical effacement (minimum -50\%).

- Presence of regular painful uterine contractions.

- Vertex presentation

\section{Exclusion criteria}

- Non-vertex presentations
- Multiple pregnancy

- Pregnancy with Bad Obstetric History

- Medical disorders complicating pregnancy like diabetes, hypertensive disorders of pregnancy, etc.

- Thrombocytopenia

- Allergy to local anesthetics.

These selected 120 parturient were actively managed during labour and were divided into 2 groups as follows and were allocated randomly to each of the groups.

Group 1 parturient receiving epidural analgesia $(4 \mathrm{~cm} . \mathrm{Cx}$ dilation placement of epidural catheter 25 cases and 35 cases $(5-6 \mathrm{~cm}) . \mathrm{Cx}$ dilation placement of epidural catheter).

Group 2 control group (parturient not receiving epidural analgesia).

\section{Methodology}

On admission detailed history is taken, maternal pulse rate and blood pressure checked, respiratory and cardiovascular system examined followed by per abdominal examination, fetal heart sound is checked. Per vaginal examination is done. If the patient satisfies the inclusion criteria, parturient consent is taken for epidural analgesia. After all investigations and preparation parturient, the parturient is positioned in either sitting or lying on her side with her knees and hips flexed. Under aseptic precautions, epidural catheter is inserted via a specially designed 16-18 G Tuohy needle into the epidural space. The space is located by incremental or continuous advancement of the needle using a loss of resistance syringe filled with a saline or air. About 2-4 $\mathrm{cm}$ of catheter is left in the identified space and the local anesthetic $0.125 \%$ ropivacaine and fentanyl $2 \mu \mathrm{g} / \mathrm{mL}$ is administered via a filter through this catheter will be given by qualified anesthesiologists in L 2-4 interspace, as often as required for the duration of labor.

\section{Monitoring}

Maternal blood pressure and pulse rate should be noted every 15 minutes (or 5 minutes for 20 minutes after each top up).

Abdominal examination every 30 minutes to know intensity, the duration and frequency of uterine contractions, descent of the head in fifths (duration and progress of labor noted using partogram). Fetal heart rate before and after each bolus and every 30 minutes, Doppler is used. The height of the block should be assessed every hour (aim for T10). Per vaginal examination to note the dilatation, effacement, station of the head indicating descent, the color of liquor. Depending on all the vitals and progress of the labor it is decided if patient will go for normal/instrumental/caesarean sections. 


\section{RESULTS}

A clinical study of 120 parturient among which 25 participants belonged to $4 \mathrm{~cm}$ dilatation epidural group (1), 35 belonged to $5-6 \mathrm{~cm}$ dilatation group (2) and 60 belong to control group (3) was done at JJM Medical College, Davangere.

Table 1: Age distribution in three groups.

\begin{tabular}{|lllc|}
\hline \multicolumn{1}{|c|}{$\begin{array}{l}\text { No. of } \\
\text { cases }\end{array}$} & \multicolumn{2}{l|}{$\begin{array}{l}\text { Age in years } \\
\text { Mean (SD) }\end{array}$} & Range \\
\hline $\begin{array}{l}\text { 4 cm Cx dilation } \\
\text { placement of the } \\
\text { epidural catheter (1) }\end{array}$ & 25 & $23.8(3.7)$ & $19-35$ \\
$\begin{array}{l}\text { 5-6 cm Cx dilation } \\
\text { placement of the } \\
\text { epidural catheter (2) }\end{array}$ & 35 & $24.3(3.3)$ & $19-32$ \\
\hline $\begin{array}{l}\text { Control (3) } \\
\text { ANOVA, F statistic=1.07 }\end{array}$ & $\begin{array}{l}\text { 21.7 (2.5) } \\
\text { P value=0.347-not } \\
\text { significant }\end{array}$ \\
\hline
\end{tabular}

There is difference in age of the pregnant women in the epidural group (both $4 \mathrm{~cm}$ and 5-6 cm) compared with a control group and this difference is statistically not significant.

The duration of I stage of labour was considered from painful palpable uterine contraction with 4 in 10 minutes with at least $50 \%$ of cervix effaced till full dilation of the cervix.

The duration of I stage of labour was shorter in the Epidural group when compared to control group and this difference is statistically significant.

Table 2: Duration of I stage of labour.

\begin{tabular}{|c|c|c|c|}
\hline \multirow{2}{*}{ Group } & \multirow{2}{*}{$\begin{array}{l}\text { No. of } \\
\text { cases }\end{array}$} & \multicolumn{2}{|c|}{$\begin{array}{l}\text { Duration of I stage } \\
\text { (hours) }\end{array}$} \\
\hline & & Mean (SD) & Range \\
\hline $\begin{array}{l}4 \mathrm{~cm} \text { Cx dilatation } \\
\text { placement of the } \\
\text { epidural catheter }(1)\end{array}$ & 23 & $7.5(1.5)$ & $6-12$ \\
\hline $\begin{array}{l}5-6 \mathrm{~cm} \mathrm{Cx} \text { dilatation } \\
\text { placement of the } \\
\text { epidural catheter (2) }\end{array}$ & 35 & $6.8(1.3)$ & $5-12$ \\
\hline Control (3) & 53 & $8.6(0.9)$ & $7-11$ \\
\hline \multicolumn{4}{|c|}{ ANOVA, F statistic $=25$} \\
\hline \multirow{3}{*}{$\begin{array}{l}\text { Mean difference } \\
\text { between the groups }\end{array}$} & $1-2$ & \multirow{3}{*}{\multicolumn{2}{|c|}{$\begin{array}{l}-0.72 \text { hours, } \mathrm{P}=0.08, \mathrm{NS} \\
1.1 \text { hours, } \mathrm{P}=0.001, \mathrm{~S} \\
1.8 \text { hours, } \mathrm{P}<0.001, \mathrm{~S}\end{array}$}} \\
\hline & $1-3$ & & \\
\hline & $2-3$ & & \\
\hline
\end{tabular}

In $4 \mathrm{~cm}$ cervical dilatation placement of epidural catheter group, the duration was 1.1 hours lower than the control group.

In 5-6 cm cervical dilatation placement of epidural catheter group, the duration was 1.8 hours shorter than the control group. There was no evidence for a statistically significant difference in duration of II stage of the labour among the three groups, though the duration was shorter in the epidural groups.

Table 3: Duration of II stage of labour.

\begin{tabular}{|lcll|}
\hline Group & $\begin{array}{l}\text { No. of } \\
\text { cases }\end{array}$ & $\begin{array}{l}\text { Duration of II } \\
\text { stage (mins) } \\
\text { Mean (SD) }\end{array}$ & Range \\
\hline $\begin{array}{l}4 \text { cm Cx dilation } \\
\text { placement of the } \\
\text { epidural catheter (1) }\end{array}$ & 23 & $\begin{array}{l}34.7 \\
(15.5)\end{array}$ & $5-90$ \\
\hline $\begin{array}{l}\text { 5-6 cm Cx dilation } \\
\text { placement the of } \\
\text { epidural catheter (2) }\end{array}$ & 35 & $\begin{array}{l}33.0 \\
(13.5)\end{array}$ & $20-85$ \\
\hline \begin{tabular}{l} 
Control (3) \\
\hline ANOVA, F statistic=1.25, P value-0.3, Not Significant
\end{tabular} \\
\hline
\end{tabular}

Table 4: Duration of III stage of labour.

\begin{tabular}{|llll|}
\hline Group & $\begin{array}{l}\text { No. of } \\
\text { cases }\end{array}$ & $\begin{array}{l}\text { Duration of III } \\
\text { stage (minutes) } \\
\text { Mean (SD) }\end{array}$ & Range \\
\hline $\begin{array}{l}4 \text { cm Cx dilation } \\
\text { placement of the } \\
\text { epidural catheter (1) }\end{array}$ & 23 & $6.6(2.7)$ & $3-15$ \\
$\begin{array}{l}\text { 5-6 cm Cx dilation } \\
\text { placement of the }\end{array}$ & 35 & $6.1(2.9)$ & $5-20$ \\
epidural catheter (2) & & & \\
\hline \begin{tabular}{l} 
Control (3) \\
\hline
\end{tabular} & 53 & $5.4(1.6)$ & $3-12$ \\
\hline
\end{tabular}

ANOVA, F statistic=2.2, P value-0.12, not significant

Duration of III stage of labour was normal, well within the stipulated 30 minutes. There was no III stage of labour complication for any participants.

Table 5: Total duration of the labour.

\begin{tabular}{|c|c|c|c|}
\hline \multirow[t]{2}{*}{ Group } & \multirow{2}{*}{$\begin{array}{l}\text { No. of } \\
\text { cases }\end{array}$} & \multicolumn{2}{|c|}{$\begin{array}{l}\text { Total duration } \\
\text { (hours) }\end{array}$} \\
\hline & & Mean (SD) & Range \\
\hline $\begin{array}{l}4 \mathrm{~cm} \mathrm{Cx} \text { dilation } \\
\text { placement of the } \\
\text { epidural catheter }(1)\end{array}$ & 23 & $8.2(1.5)$ & $6.3-12.4$ \\
\hline $\begin{array}{l}5-6 \mathrm{~cm} \text { Cx dilation } \\
\text { placement of the } \\
\text { epidural catheter ( } 2)\end{array}$ & 35 & $7.5(1.4)$ & $5.4-13.1$ \\
\hline Control (3) & 53 & $9.4(0.9)$ & $7.6-11.3$ \\
\hline \multicolumn{4}{|c|}{ ANOVA, F statistic $=25.2, \mathrm{P}$ value $<0.001$-significant } \\
\hline \multirow{3}{*}{$\begin{array}{l}\text { Mean difference } \\
\text { between the groups }\end{array}$} & $1-2$ & \multirow{3}{*}{\multicolumn{2}{|c|}{$\begin{array}{l}-0.75 \text { hours, } \mathrm{P}=0.08, \mathrm{NS} \\
1.1 \text { hours, } \mathrm{P}=0.001, \mathrm{~S} \\
1.9 \text { hours, } \mathrm{P}<0.001, \mathrm{~S}\end{array}$}} \\
\hline & $1-3$ & & \\
\hline & $2-3$ & & \\
\hline
\end{tabular}

There was no evidence for a statistically significant difference in duration of III stage of the labour among the three groups $(\mathrm{P}$ value $=0.12)$. III stage was longer in the epidural groups than control group, but this difference was not statistically significant. 
The total duration of the labour was shorter/lower in the epidural group when compared to control group and this difference is statistically significant.

In the 4-cm group, the duration was 1.1 hours (P Value $=0.001$ ) lower than the control group. In $5-6 \mathrm{~cm}$ group ( $\mathrm{P}$ value $<0.001)$, the duration was 1.9 hours shorter than the control group.

Mean duration of labour in all the three groups was well within 12 hours. All actively managed parturient should deliver within 12 hours.

Table 6: Mode of delivery in three group.

\begin{tabular}{|c|c|c|c|c|}
\hline Mode of delivery & $\begin{array}{l}4 \mathrm{~cm} \text { dilation placement of } \\
\text { epidural catheter group (1), } \\
\text { n (\%) }\end{array}$ & $\begin{array}{l}\text { 5-6 cm dilation placement of } \\
\text { epidural catheter group (2), } \\
\text { n (\%) }\end{array}$ & $\begin{array}{l}\text { Control group } \\
(3), \mathrm{n}(\%)\end{array}$ & Total \\
\hline FTVD & $22(88.0)$ & $33(94.2)$ & $45(75.0)$ & 100 \\
\hline Forceps & $1(4.0)$ & $1(2.9)$ & $5(8.3)$ & 7 \\
\hline Vacuum & $0(0)$ & $1(2.9)$ & $3(5.0)$ & 4 \\
\hline LSCS & $2(8.0)$ & $0(0)$ & $7(11.7)$ & 9 \\
\hline Total & 25 & 35 & 60 & 120 \\
\hline
\end{tabular}

Chi squared $=7.76, \mathrm{P}=0.256$, not significant

The percentage of instrumental deliveries was lower among the epidural groups compared to control group. Also, LSCS $(11.7 \%)$ was higher in control group compared to $8 \%$ in $4 \mathrm{~cm} \mathrm{Cx}$ dilatation placement of epidural catheter group and none $(0 \%)$ in $5-6 \mathrm{~cm} \mathrm{Cx}$ dilatation placement of epidural catheter group. Vaginal delivery in group (1), group (2) and group (3) was $88 \%$, $94.2 \%$ and $75 \%$ respectively.

\section{In $4 \mathrm{~cm}$ dilation placement of epidural catheter Group (1)}

- Instrumental delivery - 1

- Ind - Failure of secondary forces, 2 LSCS

- Ind - 2 Fetal distress

\section{In 5-6 cm dilation placement of epidural catheter Group} (2)

- Instrumental deliveries

- Ind - Failure of secondary forces (vacuum) I

- Ind - Fetal distress, LSCS is none.

\section{In control group (3)}

- 8 instrumental deliveries

- 3 Vacuum deliveries

- Ind - 2 Fetal distress and 1 Failure of secondary forces. 5 forceps deliveries

- Ind - 3 Fetal distress and 2 Failure of secondary forces. 7 LSCS

- Ind - 6 Fetal distress and 1 cervical dystocia.

Table 7: NICU admission in three groups.

\begin{tabular}{|c|c|c|c|c|}
\hline $\begin{array}{l}\text { NICU } \\
\text { Admission }\end{array}$ & $\begin{array}{l}4 \mathrm{~cm} \text { dilation placement of } \\
\text { epidural catheter } \mathrm{n}(\%)\end{array}$ & $\begin{array}{l}5-6 \mathrm{~cm} \text { dilation } \\
\text { placement of epidural } \\
\text { catheter } \mathrm{n}(\%)\end{array}$ & Control n (\%) & Total \\
\hline Yes & $1(4.0)$ & $1(2.9)$ & $3(5)$ & 5 \\
\hline No & $24(96.0)$ & $34(97.1)$ & $57(95)$ & 115 \\
\hline Total & 25 & 35 & 60 & 120 \\
\hline
\end{tabular}

There is no increase in caesarean section rate in the parturient receiving epidural group.

NICU admissions in all 3 groups were nearly similar. No statistical significance ( $P$ value 0.22 ). All the babies admitted to NICU recovered and were discharged from the hospital in good health. No perinatal morbidity and mortality were seen in any of the 3 groups.

There was no statistically significant difference in APGAR score categories among three groups. 1-minute APGAR score range from 4-7, In the 4.c.m cervical dilatation placement of epidural catheter group, 5-6.c.m 
cervical dilatation placement of epidural catheter group and control group was 92\%, 94.2\%, and $90.0 \%$ respectively.

Table 8: APGAR at 1 minute and epidural anaesthesia.

\begin{tabular}{|c|c|c|c|c|}
\hline $\begin{array}{l}\text { APGAR } \\
\text { at } 1 \\
\text { minute }\end{array}$ & $\begin{array}{l}4 \mathrm{~cm} \\
\text { catheter } \\
\text { placement } \\
\mathrm{n}(\%)\end{array}$ & $\begin{array}{l}5-6 \mathrm{~cm} \\
\text { catheter } \\
\text { placement } \\
\text { n }(\%)\end{array}$ & $\begin{array}{l}\text { Control } \\
\text { n ( } \%)\end{array}$ & Total \\
\hline$<4$ & $1(4.0)$ & $1(2.9)$ & $6(10)$ & 8 \\
\hline $4-7$ & $23(92.0)$ & 33 (94.2) & $\begin{array}{l}54 \\
(90.0)\end{array}$ & 110 \\
\hline$>7$ & $1(4.0)$ & $1(2.9)$ & $0(0)$ & 2 \\
\hline Total & 25 & 35 & 60 & 120 \\
\hline
\end{tabular}

Chi squared $=4.18 ; \mathrm{P}=0.38$, Not significant

Table 9: APGAR at 5 minute and epidural anaesthesia.

\begin{tabular}{|lllll|}
$\begin{array}{l}\text { APGAR } \\
\text { at 5 } \\
\text { Minute }\end{array}$ & $\begin{array}{l}\text { 4cm } \\
\text { catheter } \\
\text { placement } \\
\text { n(\%) }\end{array}$ & $\begin{array}{l}\text { 5-6 cm } \\
\text { catheter } \\
\text { placement } \\
\text { n(\%) }\end{array}$ & $\begin{array}{l}\text { Control } \\
\text { n } \%)\end{array}$ & Total \\
\hline $4-7$ & $20(80.0)$ & $27(77.1)$ & $\begin{array}{l}33 \\
(55.0)\end{array}$ & 80 \\
\hline$>7$ & $5(20.0)$ & $8(22.9)$ & $\begin{array}{l}27 \\
(45.0)\end{array}$ & 40 \\
\hline Total & 25 & 35 & 60 & 120 \\
\hline
\end{tabular}

Chi squared=7.4, $\mathrm{P}=0.03$, Significant

There was statistically significant difference in APGAR score categories among three groups (P value 0.03 ). Control group have babies whose APGAR score more than 7 at 5 minutes as $45 \%$ compared to $20 \%$ in $4 \mathrm{~cm}$ group and $23 \%$ in $5-6 \mathrm{~cm}$ group.

\section{DISCUSSION}

In the present study the placement of epidural catheter at $4 \mathrm{~cm}$ of cervical dilatation, the age group ranged from 19 to 35years with mean age of 23.8years. In the $5-6 \mathrm{~cm}$ cervical dilatation placement of catheter group the age group ranged from 19 to 32 years with mean age of 24.3 years. In the control group the age group ranged from 19 to 30 years with mean age of 21.7 years.

In study by the Rimaitis $\mathrm{K}$ et al, the mean age in the epidural group was the 26.5 years. ${ }^{3}$ In study by the Rimaitis $\mathrm{K}$ et al the mean age in control group was the 26.4 years. $^{3}$ In study by the Halvadia $\mathrm{SH}$ et al, in the epidural group ranged from 20-25 years with the mean age of 21.9 years. $^{6}$

In study by Mousa WF et al, the mean age in epidural group was 26.5 years and control group was 25.5 years. $^{7}$

In the present study all 120 participants were actively managed during the labour and in those 120 cases 25 participants belong to placement epidural catheter a $4 \mathrm{~cm}$ the cervical dilatation another 35 participants belong to placement of the epidural catheter at 5 to $6 \mathrm{~cm}$ group and remaining 60 participants in control group.

Table 10: Duration of different stages of labour in three groups.

\begin{tabular}{|lllll|}
\hline Group & $\begin{array}{l}\text { I stage } \\
\text { (hours) }\end{array}$ & $\begin{array}{l}\text { II } \\
\text { stage } \\
\text { (mins) }\end{array}$ & $\begin{array}{l}\text { III } \\
\text { stage } \\
\text { (mins) }\end{array}$ & $\begin{array}{l}\text { Total } \\
\text { duration } \\
\text { (hours) }\end{array}$ \\
\hline $\begin{array}{l}\text { cm Cx } \\
\text { dilation (1) }\end{array}$ & $\begin{array}{l}7.5 \\
(1.5)\end{array}$ & $\begin{array}{l}34.7 \\
(15.5)\end{array}$ & $\begin{array}{l}6.6 \\
(2.7)\end{array}$ & $8.2(1.5)$ \\
\hline $5-6 \mathrm{~cm} \mathrm{Cx}$ & 6.8 & 33.0 & 6.1 & $7.5(1.4)$ \\
dilation (2) & $(1.3)$ & $(13.5)$ & $(2.9)$ & \\
\hline Control (3) & $\begin{array}{l}8.6 \\
(0.9)\end{array}$ & $\begin{array}{l}38.6 \\
(19.8)\end{array}$ & $\begin{array}{l}5.4 \\
(1.6)\end{array}$ & $9.4(0.9)$ \\
\hline
\end{tabular}

There is no statistically significant difference in the duration of I stage/II stage/III stage and total duration of the labour among the three groups.

Statistically significant difference present in the duration of I stage of labour between 5-6 cm. Cervical dilation placement of epidural catheter group and $4 \mathrm{~cm}$ cervical dilation placement of epidural catheter group and 5-6 cm cervical dilation placement of epidural catheter group as well as and control group.

\section{Table 11: Study by Rimaitis K et al}

\begin{tabular}{|llll|} 
Stage & $\begin{array}{l}\text { Epidural } \\
\text { group }(n=80)\end{array}$ & $\begin{array}{l}\text { Control group } \\
(n=80)\end{array}$ & P valve \\
I hrs & $78(1.5)$ & $7(1)$ & 0.4 \\
\hline II mins & $56(10)$ & $42(12)$ & 0.3 \\
\hline
\end{tabular}

No statistical significance.

There is no statistically significant difference present in the duration of II stage of labour between 5-6 cm ervical dilation placement of epidural catheter group and $4 \mathrm{~cm}$. Cervical dilation placement of epidural catheter group and $5-6 \mathrm{~cm}$. Cervical dilation placement of epidural catheter group as well as and control group.

Table 12: Study by Mousa WF et al

\begin{tabular}{|llll} 
Stage & $\begin{array}{l}\text { Epidural } \\
\text { group }(n=80)\end{array}$ & $\begin{array}{l}\text { Control group } \\
(\mathrm{n}=80)\end{array}$ & $\begin{array}{l}\mathrm{P} \\
\text { valve }\end{array}$ \\
\hline I hours & $8(1.4)$ & $9(1.2)$ & 0.35 \\
II minutes & $65(15)$ & $50(10)$ & 0.41 \\
\hline
\end{tabular}

No statistical significance.

In the study by the Howell 8et al, 2001 the mean duration of first stage of the labour and second stage of labour was 5hours 32 minutes and 62 minutes respectively.

In Present study vaginal delivery rate in the 4.c.m cervical dilatation placement of epidural catheter group, 5-6.c.m cervical dilatation placement of epidural catheter group and control group was $88 \%, 93 \%$ and $75 \%$ 
respectively. There is no statistical significance. The Instrumental assisted delivery rate in the 4.c.m cervical dilatation placement of epidural catheter group, 5-6.c.m cervical dilatation placement of epidural catheter group and control group was $4 \%, 5.8 \%$, and $13.3 \%$ respectively. There is no statistically significant difference

LSCS rate in the 4.c.m cervical dilatation placement of epidural catheter group, 5-6 cm cervical dilatation placement of epidural catheter group and control group was $8 \%, 0 \%$ and $11.7 \%$ respectively. There is no statistical significance. In the study by the Rimaitis $\mathrm{K}$ et al, instrumental assisted vaginal delivery is $2.16 \%$ There was no significant association between the use of Epidural analgesia and increased Instrumental assisted vaginal delivery rate $(\mathrm{OR}=0.81 ; 95 \% \mathrm{CI}, 0.60-1.09){ }^{3}$

In the study by the Halvadia $\mathrm{SH}$ et al, spontaneous vaginal delivery rate was $57.5 \%$, instrumental assisted vaginal delivery $21 \%$ and LSCS rate was $20 \%$. In the study by the Howell et al instrumental assisted vaginal delivery is $2.9 \%$ and LSCS rate was $7.1 \%$ in the epidural group and in the control group was $1.9 \%$ and $10.6 \%$ respectively. ${ }^{8}$ In the study by the Nafisi et al, instrumental assisted vaginal delivery $2 \%$ and LSCS rate was $12.18 \%$ in the epidural group and in the control group was $2 \%$ and $9.59 \%$ respectively. ${ }^{9}$

\section{CONCLUSION}

Epidural analgesia endeavors to make child birth a pleasurable and painless experience. Epidural analgesia since the time it has been adopted has always been advocated by various investigators as to cause an increase in duration of the labour and increase the instrumental delivery rate and caesarean section rate. Present study on the contrary shows a trend towards decrease in the duration of the labour as well as instrumental delivery and caesarean section rate. A good APGAR score of all the babies in our series goes way in proving its safety with regards to the fetus and neonate as well Judging from the favourable outcome and wide applicability, it is concluded that epidural analgesia technique along with active management of the labour may be recommended for routine use in institutions. If properly conducted with meticulous supervision, it would provide the expectant mother with all the satisfaction of a normal child birth without the agony of labour pain.
Funding: No funding sources Conflict of interest: None declared

Ethical approval: The study was approved by the Institutional Ethics Committee

\section{REFERENCES}

1. Vincent RD Jr., Chestnut DH. University of Alabama School of Medicine, Birmingham, Alabama. Epidural analgesia during labor. Am Fam Phy. 1998;58(8):17851792.

2. Satpathy HK, Chief editor: Alex Macario. Labor and delivery, analgesia, regional and local: overview, indications, contraindication. Available at http://emedicine.medscape.com/article/149337overvi ew\#a8.

3. Rimaitis K, Klimenko O, Rimaitis M, Morkūnaitè A, Macas A. Labor epidural analgesia and the incidence of instrumental assisted delivery. Medicina. 2015;51(2):76-80.

4. Anim-Somuah M, Smyth RMD, Jones L. Epidural versus non-epidural or no analgesia in labour. Cochrane Database Systematic Rev. 2011;12:CD000331.

5. Meister, Greg C. A comparison of epidural analgesia with $0.125 \%$ ropivacaine with fentanyl versus $0.125 \%$ bupivacaine with fentanyl during labour. Anesthesia Analgesia. 2000;90(3):632-7.

6. Halvadia SH, Halvadia HB, Joshi RM, Upadhyaya DP. A study of feto maternal outcome of epidural analgesia during labor. Natl J Med Res. 2013;3:1846.

7. Mousa WF. Epidural analgesia during labor versus no analgesia: a comparative study. Saudi J Anaesth. 2012;6(1):36-40.

8. Howell CJ, Kidd C. Randomized controlled trial of epidural compared with non-epidural analgesia in labour. BJOG. 2001;108(1):27-33.

9. Nafisi, Shahram. Effects of epidural lidocaine analgesia on labour and delivery: a randomized, prospective, controlled trial. BMC Anesthesiol. 2006;6(1):15.

Cite this article as: Madhu KN, Kumar DHR. Fetomaternal outcome in subject undergoing epidural labour analgesia with Ripovacaine and Fentanyl. Int J Reprod Contracept Obstet Gynecol 2018;7:659-64. 